\title{
ENGLISH VERS LIBRE PROSODY (AUDITORY ANALYSIS RESULTS)
}

\author{
Olga Morgunova \\ Mariupol State University, Ukraine \\ msmorgunova07@gmail.com \\ Tetiana Shkurko \\ a linguist, Kyiv, Ukraine, \\ shkurko.tatyana07@gmail.com \\ Olena Pavlenko \\ Mariupol State University, Ukraine \\ h.pavlenko@mdu.in.ua
}

\begin{abstract}
The paper focuses on the vers libre prosody taking into account the auditory aspect of its oral actualisation. The main hypothesis of the study is that vers libre is constituted with a range of definite stable prosodic features that allow referring it to versification and at the same time to something different from a metered text and prose. Stimuli include written and oral presentations of vers libre. Some prosaic extracts have been analysed to compare them with vers libre. In addition, vers libre has been written as a piece of prose (pseudo-prose) and recited orally by native speakers having RP pronunciation. The prose has been written as vers libre, i.e. divided into lines (pseudo-verse), and cited as a verse. It helps identify the role of prosodic features in constituting vers libre specificity. The authors come to the conclusion that vers libre is correlated with a rather comprehensive set of prosodic features that determine its specificity. The quality of the "poetic speech" is formed by all components of its prosodic structure. The most important poetic features of vers libre are presented by its accent system and rhythmical structure. The accentual features include decentralisation of an accent in free verse lines; the rhythmic dominant on the last ictus in the line; an additional emphasis in polysyllabic words. The typical rhythmic structures in the vers libre are monosyllabic $1 / 1$, disyllabic $2 / 2,2 / 1$, three-syllabic $3 / 2,3 / 3$ and four-syllablic $4 / 3$ ones. The difference between vers libre and prose is demonstrated mainly by temporal and pausal features.
\end{abstract}

Keywords: vers libre; auditory analysis; poetic speech; prosody; accentuation; rhythm.

\section{Introduction}

The main feature of poetic speech was defined as the regular occurrence of phonetic representations (syllable, syllable combination, vowel and consonant sound representations) (Polivanov, 1963; Aroui \& Arleo, 2009, etc.). The elimination of traditional verse properties (meter, rhyme, etc.), the absence of typically verse "prompts" (inversions, repetitions) in some vers libre varieties on lexical and syntactic levels make this versification close to prose.

There exist a considerable number of works, dealing with the prosody of metrical verse, which account for the importance of different features (tonal, temporal, accentual, etc.) that contribute to the prosodic specificity of poetry. Such works are focused on the analysis of the prosodic features of poems according to the authors' styles (Fabb, \& Halle, 2006; Guseva, 2007) as well as study the verses referring to a certain period or genre (Hench, \& Estes, 2018; Vorobey, 2011; Knyazeva, 2012; Logvin, 1989; Suslova 2005; Tokareva, 2009). A significant number of works look into the rhythm in literary (mainly poetic) texts (Esser, 2011; Grigoryan, 2004; Gumovskaya, 2000; Harding, 2010; Kalashnikova, 2013; Mirianashvili 2007; Smus', 1988; Shevelyova-Garkusha, 2013; Zabuzhanska 2016). Some works place greater focus on certain prosodic characteristics such as the temporal component (Cureton, 2017; Karpichenkova, 1981; Titova, 2009).

The study of prosody of free verse is of a particular interest since the vers libre stands out due to its form against the background of the traditional poetics of any nation (Bittner, 1997; Kachalkina, 2004; Zhovtis, 2013). And if there is no need to justify the right to the existence of classical versification systems, then the status of free verse is still debated in current science. The concept of the so-called "negative" definition of free verse, according to which it has no formal signs of poetic speech, has not yet been rejected. Vers libre is often defined as "non-metrical" verse, which means that "there are no patterns to the verse" (Steel, 1990). Some definitions of free verse are rather vague. According to Timofeyev \& Vengrov (1963), vers libre is characterised by the arbitrary number of stressed and unstressed syllables, the absence of recurring uniform stanzas and rhymes. Its "homogeneous syntactic organisation" defines "a homogeneous intonation, with which each of the verse lines and phrases of free verse is pronounced", hence, "the free rhythm of the poem" (p. 137).

But, nevertheless, in modern science, another tendency is becoming stronger, whose representatives are

Morgunova, O., Shkurko, T., \& Pavlenko, O. (2019). English vers libre prosody (auditory analysis results). Advanced Education, 13, 11-17. DOI: $10.20535 / 2410-8286.147603$ 
looking for constructive signs of vers libre, rightly believing that free verse is characterised by certain regularities.

The analysis of phonetic works dealing with poetic studies proves that they do not take into consideration the prosodic features of poetry in a broad sense of this word, which is shown in the following review of phonetic monographs and articles. According to the majority of studies (see, for instance, Hartman, 1996; Finch, 2000), the most important features in poetic forms are, by no means, the rhythmic ones. Some researchers emphasise that poetic prosody belongs to the sphere of poetics as a subsection of rhetoric (Andrews, 2016) rather than to linguistics. In (Scott \& Evans, 2012), the authors underline the importance of "locating (this) verse at the intersection of multiplied coordinates": rhyme, repetition, etc., and relating to the study of linguistic structures: "tempo, pause, tone, accentual variations..." (p. 1518). As cited in (Aroui \& Arleo, 2009), Duhamel and Vildrac state that syntactical parallelism "rhythmically energises the verse", thus the verse is based not "on controlling metric of a syllabic count, but on syntax..." (p. 101). In addition, the authors pay attention to the fact that "the metrical structure of free verse depends on the simultaneous cooperation of all metrically relevant factors" (Bittner, 1997, p. 3). Among the factors which determine the specifics of vers libre versification ("metrically relevant factors"), they mention syntax, lexical stress and "metro-rhythmic idealisation" (Bittner, 1997, p. 3). It is also pointed out that the form of vers libre is influenced by the "specific segmentation of the discourse characteristic of the written poetry of the modern Western European tradition" (Murat, 2008, p. 34), while its segmentation is presented graphically due to the transition to a new line (Belavina, 2017).

It is evident that the prosodic structure of free verse is a specific phenomenon. In this regard, it will be interesting to find out how the material substance of free verse is structured, what is common in the prosodic organisation of vers libre with other versification systems, the combination of which components allows speaking about the specifics of this genre. Thus the relevance of the study of such a poetic form as free verse is caused by the necessity to define its status, revealing the constitutive characteristics of a free verse at the prosodic level of its organisation.

The research object is the English poetic speech in its genre variety of free verse. The aim of this work is to identify and describe the patterns of prosodic explication of free verse.

The main hypothesis of the study is that vers libre is constituted with a range of definite stable prosodic features owing to which it can be attributed to versification and at the same time it is perceived as something different from a metered text and prose.

The presented above review of the studies of free verse in modern linguistics shows that the following factors are relevant in defining the prosodic features of vers libre:

1) the hierarchy of rhythmic units (lines, rhythmic groups, etc.), organising the free verse read aloud;

2) different line compositions of free verse (when the line is the main rhythmic unit of the poetic work and when the rhythm-forming function of line breaks in vers libre).

\section{Methodological Background}

To ascertain the prosodic characteristics of vers libre, we performed a theoretical analysis of the literature on the problem, auditory analysis of experimental material as well as mathematical processing of the data obtained (Brovchenko et al., 1976; Dvorzhetskaya, \& Steriopolo, 1991). In identifying the features of accentuation of free verse, the analysis of its accentual patterns according to the method suggested by Zlatoustova (1962a, 1962b) (in terms of rhythmic structures) turned out to be very effective.

Stimuli were presented by vers libre and prosaic excerpts to compare them with vers libre. The material under study includes audio recordings and texts of 200 vers libre and prosaic excerpts of the 20th centuries, voiced by their authors and/or narrators, native speakers of English. The total duration of the recordings under analysis is 293 minutes.

We took into consideration the conclusion made by Zhovtis related to the so-called verse specifics, which exists due to the graphic segmentation and a system of interlinear pauses. "The vers libre remains faithful to the verse and is a verse, not prose, because it reveals the correspondence of lines graphically singled out by the author's attitude to the verse. $<\ldots>$ The presence or absence of an adjustment in correspondence should serve as a basis for attributing the work to either verses or prose" (Zhovtis, 2013, p. 30).

The auditory analysis included three stages. The purpose of the first stage is to identify the type of literary speech in accordance with prosodic information. In order to perform this task, vers libre has been written as a piece of prose (pseudo-prose) and then read aloud and recorded by native speakers having RP pronunciation. The prose has been presented as vers libre (pseudo-verse) and cited as a verse. The task of the auditors - native speakers - was to identify the stimulus (when listening to oral representations of free verse, an excerpt from fiction, their transformations) without relying on the text using the notation: artistic 
prose - verse. The order of listening is intentionally spontaneous.

At the second stage of auditing, it was necessary to trace the presence / absence of the redistribution of boundaries between the lines of the verse as compared with the original written version of the free verse. For this, the auditors were offered to transform the poems into written form.

At the third stage of the auditory analysis, the phoneticians were asked to divide the texts into syntagmas, denoting pauses (temporal pauses-breaks and pauses-lengthenings, as well as non-temporal pauses), the duration of temporal pauses as well as to present graphically the accentual and melodic structure of the syntagma, note stress peculiarities (decentralised / centralised), characterise the temporal differences of the speech segments and the heterogeneous nature of the tempo (if any) in the polysyllabic segments, identify the segments characterised by rhythm and specify the isochronous speech segments. The correctly identified prosodic representations were taken as experimental material for the next stage of the auditory analysis. The phonetic analysis allowed us to identify the perceived characteristics of the texts under study.

\title{
Results and Discussion
}

All vers libre prosodic features create its poetic form. The results of the auditory identification of poetic and prose realisations revealed that prosodic features are a fairly reliable factor in determining the type (prosaic or poetic) of speech. The probability of correct recognition of poetic and prosaic realisations is up to $80 \%$. This is a sufficiently high indicator, considering that the texts for listening were recorded in a deliberately random order.

The typical features of vers libre are manifested in the distribution of tonal characteristics (a set of tones, their range, the distribution of scales).

Terminal part in vers libre lines is represented mainly by simple tones. The most frequent among them are the falling ones $(81.3 \%)$. Complex tones rarely occur in our experimental material (the falling-rising divided tone and the falling-rising tone $(2.1 \%)$ ). There is a certain specificity of the use of terminal tones in vers libre: a narrow range of falling pitch is common to it (44.2\%). Falling tones at the end of the vers libre lines present its typical prosodic parameter:

\author{
My 'mother'slams the $\rightarrow$ door \\ on her 'star-cluster of $\backslash$ dregs \\ and 'packs me off to bed. (Muldoon, 1983, p. 52) \\ 'Virgin $\square$ 'mountaintop $\square$ s snow (Mair, 1979, p. 40) \\ My 'life is a 'curtained,window, \\ A re'fraction of light in the omirror, \\ I am a 'flash in a'snow-covered field, \\ 'Brilliant in brightness, \\ Not a 'torch in the , mist \\ But a 'clear daylight. (Holt, 1973, p. 38)
}

The conclusion about the use of the falling tones of the narrow range at the end of a verse line coincides with the observations of other researchers (Safronova, 1982, p. 55). This feature can be identified as specific for verses. Prosaic texts demonstrate a smaller frequency of usage of tones of a low range (cf.: “... the pitch interval determining the fall of the tone in the last syntagma of the phrase in prose speech is not typical for poetic speech (Zlatoustova, 1962a, p. 27)). According to our findings, it is by 2.4 less than in poetic texts.

The distribution of scales in the material under study also demonstrates certain regularities. The auditory analysis of the pre-terminal part of the syntagms in vers libre reveals that the movement of melody is mainly descending. Gradually descending scales (vers libre $-68.5 \%$, cf.: pseudo-verse $-63.8 \%$ ) and broken descending sliding scales (vers libre $-18.1 \%$, cf.: pseudo-verse $-15.7 \%$ ) are most frequent among descending scales.

The terminal levelling is characteristic of the end-of-line position (vers libre $-13.5 \%$, cf.: pseudo-verse $-10.7 \%)$ :

' Doing her 'morning fan_dango

'Kitty $\square$ despairing $\rightarrow$ newspaper $\square$ (Mair, 1979, p. 34)

The conclusion about the end-of-the-line levelling in vers libre coincides with the findings of other linguists (cf.: "In unrhymed ... ver libers there is an alternation of the descending melodic contour ( $($ ) with the level one $(\rightarrow)$ (Zabuzhanska, 2016, p. 107).

In prose, the intonation contour most often includes a gradual descending scale $(82,7 \%)$. This figure is 
higher than that in vers libre. In some cases of the prose text, a sliding scale appears. Gliding creates the effect of increased emotionality in prose and is due, as a rule, to the communicative type of the sentence, e.g.:

A fine day, a glowing day. Oh, $\uparrow$ bright, sharp air! (Coppard, p. 531).

The most important verse qualities are presented by its specific accent system and rhythmical structure (RS), formed by a set of phenomena.

They include the frequent occurrence of strongly stressed functional words resulting in their prosodic self-dependence and, hence, stress decentralisation in most vers libre lines:

I have eaten

the plums

that were in

the icebox (vers libre) (Wain, 1963, p. 57).

The same tendency is revealed by other authors investigating the poetic speech. Thus, Agirrezabal, Alegria and Hulden (2016) pay attention to what they call "complications" (p.772) which arise in the following line from the ninth book of Paradise Lost, by John Milton:

No more of talk where God or Angel guest

With Man, as with his friend, familiar us'd,

To sit indulgent, and with him partake.

They state that "in the second line above, we see that the word 'with' appears as both unstressed and stressed, showing that the process of assigning prominence to certain syllables cannot depend purely on the lexical items themselves" (Agirrezabal et al., 2016, p. 772);

The tendency to the similar anacruses is traced in vers libre lines:

I said I love you

Beside the banks of the river (vers libre) (Mair, 1979, p. 58).

I said I love you be side the banks of the river (pseudo-prose).

The appearance of the rhythmic dominant on the last ictus of a verse line is a characteristic feature of vers libre.

Additional stresses in polysyllabic words are due to the alternating placement of prominence peaks:

and the world pirouetted (pseudo-prose) $\rightarrow$ and the world pirouetted (vers libre) (Mair, 1979, p. 58);

overshadowed and so forgotten (pseudo-prose) $\rightarrow$ overshadowed and so forgotten (vers libre) (Holt, 1973, p. 17).

Such frequent structures as one-syllable $1 / 1$, two-syllable $2 / 2,2 / 1$, three-syllable $3 / 2,3 / 3$ and foursyllable $4 / 3$ ones are presented in vers libre.

Masculine clausula is singled out in most vers libre lines:

among stricken trees (pseudo-prose) $\rightarrow$ among stricken trees (Hughes, 1983, p. 27);

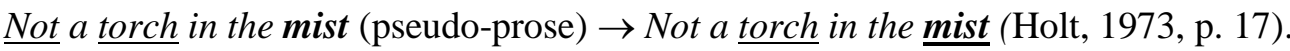

A frequent transfer of prominence peaks from the first syllable to the last one in three-syllable RSs at the end of lines and rhythmical uniformity in line cadences have been identified.

The difference between vers libre and prose is also marked by a set of temporal and pausal peculiarities.

One of them is the tendency to pause isochronism in vers libre, in most cases, the end-of-line pauses of average duration:

Doing her morning fandango

Kitty despairing newspaper|

And TV reports

Decided to send a message

To the little flower company

In Madras India

After she polished the floor. ||| (vers libre) (Mair, 1979, p. 34);

Doing her morning fandango $\mid$ Kitty despairing newspaper and TV reports $\mid$ decided to send a message to the little flower company in Madras | India | after she polished the floor. || (pseudo-prose).

Prose (pseudo-prose) tone-groups sound at the moderate tempo $(60,0 \%)$ are combined mainly with average pauses $(53,0 \%)$. Verse tone-groups are realised at the slow tempo $(63,1 \%)$ and are delimited with the average pauses. Verse tone-groups are characterised with the complex tempo modulations as compared to prosaic ones. This may be the acceleration or retardation of tempo at the verse polysyllabic blocks.

As a result of the experimental-phonetic study of the free verse prosody, the initial hypothesis about the 
correlation of the vers libre with a rather comprehensive specific set of prosodic peculiarities that determine its specificity was confirmed. An integrated approach to the study of prosody of vers libre allowed representing its prosodic structure as a hierarchical system of interacting components outlined above.

A number of prosodic features that determine the specific character of vers libre include qualities typical of poetic speech presented in the verse read aloud. The presence of these characteristics in the prosodic structure of the free verse is quite natural, since it is not a completely autonomous and isolated system, but organically complements the variety of poetic forms.

Actually, the poetic nature of the vers libre is determined by a rather comprehensive set of stable prosodic features. The quality of the "poetic speech" is formed by all the outlined above components of its prosodic structure. It is important for the vers libre, as it lacks meter.

The tonal features of vers libre include high recurrence of the low and medium descending tone of the narrow range and a level tone of the low and medium variety, the use of terminal levelling at the end-of-line position, the usage of gradually descending and broken descending sliding scales typical of poetic speech.

The specificity of the temporal organisation of a free verse lies in the fact that the end of most lines is marked with a pause, and the relationship between the length of the pause and its recurrence is often marked by a negative correlation, i.e. the longer is the pause, the less is its frequency of occurrence at the end of a verse line. The realisation of most syntagms of vers libre at a moderate tempo along with the abovementioned feature is also a typical characteristic of the temporal specifics of the verse.

As it was demonstrated by the examples, the greatest number of typical poetic characteristics is represented by the accentuation system and features of the rhythmic structure. Thus, the presence of a prominent syllable as a part of almost all auto-semantic words and the frequent singling out of functional words with a primary accent leads to their prosodic independence, which ensures decentralisation of an accent in most lines of free verse.

The specific verse tendencies present in the vers libre also manifest themselves in their pursuit of the same beginning of verse lines, the appearance of the rhythmic dominant on the last ictus in the line, an additional emphasis in polysyllabic words due to alternating placement of peaks of prominence in the English speech.

The study of the rhythmic structure of free verse showed the presence of such frequent rhythmic patterns in the vers libre as monosyllabic $1 / 1$, disyllabic $2 / 2,2 / 1$, three-syllabic $3 / 2,3 / 3$, four-syllabic $4 / 3$ ones. Taking into account the rhythmic structures at the end of a vers libre line, it was possible to note the same figuration in the majority of lines by the male clausula. In addition, the frequent shift of the peak of prominence from the first syllable to the last one in the three-syllable rhythmic structure at the end of the line contributed to the appearance of rhythmic uniformity in the cadence of the lines. The number of identical and synonymous rhythmic structures is large enough to speak of an anaphoric accent rhyme in vers libre.

\section{Conclusions}

The experimental phonetic research of vers libre prosody (its auditory aspect) has confirmed the hypothesis of the vers libre definite prosodic features owing to which it is attributed to versification and at the same time it is perceived as something different from a metered text and prose.

The prosodic portrait of vers libre is characterised by a considerate number of invariant features. The most important verse qualities of vers libre are presented by the accent system and rhythmical structure. The accentual features include decentralisation of an accent in free verse lines; the rhythmic dominant on the last ictus in the line; an additional emphasis in polysyllabic words. The typical rhythmic structures in the vers libre are monosyllabic $1 / 1$, disyllabic $2 / 2,2 / 1$, three-syllabic $3 / 2,3 / 3$ and four-syllablic $4 / 3$ ones. The tendency to the male clausula and an anaphoric accent pattern is traced in vers libre lines. The tonal specifics of vers libre is manifested in low and medium descending tone of a narrow range; level tone of the low and medium variety within the lines. As for the scales, they are frequently gradually descending scales. The terminal levelling is characteristic of the end-of-line position. The temporal and pausal invariant features of vers libre include pause isochronism, the end-of-line pauses of average duration and realisation of verse tone-groups with a slow tempo.

In order to proceed with a comprehensive survey of vers libre prosodic features, it is necessary to carry out further studies into its acoustic specificity. Typological aspects are of special interest as well.

\section{References:}

Agirrezabal, M., Alegria, I., \& Hulden, M. (2016). Machine Learning for Metrical Analysis of English Poetry. In Proceedings of COLING, the 26th International Conference on Computational Linguistics: Technical Papers (pp.772-781). Osaka, Japan.

Andrews, R. (2016). A Prosody of Free Verse: Explorations in Rhythm. New York: Routledge. 
Aroui, J.-L. \& Arleo, A. (2009). Towards a Typology of Poetic Forms: From Language to Metrics and Beyond. Amsterdam: John Benjamins Publishing.

Belavina, E. (2017). From Verlaine to Vers Libre: The Evolution of the Dominant of Auditory Imagination. Novoje Literaturnoje Obozrenije, 148. Retrieved March 15, 2018 from https://www.nlobooks.ru/magazines/ novoe_literaturnoe_obozrenie/ 148_nlo_6_2017/article/19338/.

Bittner, H. (1997). The Metrical Structure of Free Verse. PhD Thesis, School of Modern Languages and European Studies, University of East Anglia. Retrieved July 20, 2016 from https://www.uni-hildesheim.de/media/_migrated/ content_uploads/The_Metrical_Structure_of_Free_Verse.pdf.

Brovchenko, T. A., Varbanets, P. D., \& Taranets, V. G. (Eds). (1976). Metod statisticheskogo analiza v foneticheskih issledovanijah: ucheb. posob. [Statistical Analysis in Phonetic Studies: manual]. Odessa: Izd-vo Odess. gos. un-ta im. Il'i Mechnikova.

Coppard, A.E. (1976). Fifty Pounds. In The Collected Tales of A.E. Coppard. New York: Ayer Co Pub.

Cureton, R. (2017). A Reading in Temporal Poetics: Wallace Steven's Domination of Black. Style, 51(4), 526-549. https://doi.org/10.5325/style.51.4.0526

Dvorzhetskaya, M. P., Steriopolo, Ye. I., Valigura, O.R., etc. (Eds). (1991). Metody jeksperimental'no-foneticheskogo issledovanija zvuchashhej rechi: [ucheb. posob. po teoreticheskoj fonetike inostrannyh jazykov] [Experimental Phonetic Methods for Spoken Language Research: [manual on theoretical phonetics of foreign languages]. Kiev: Kiev. gos. ped. in-t inostr. jazykov.

Esser, J. (2011). Rhythm in Speech, Prose and Verse: A Linguistic Description. Berlin: Logos Verlag.

Fabb, N. \& Halle, M. (2006). Metrical Complexity in Christina Rossetti's Verse. College Literature, 33(2), 91-114. https://doi.org/10.1353/lit.2006.0019

Finch, A. (2000). The Ghost of Meter: Culture and Prosody in American Free Verse. Ann Arbor, MI: University of Michigan Press.

Grigoryan, I. T. (2004). Ritm i prosodija hudozhestvennogo teksta v pragmastilisticheskom osveshhenii [Rhythm and Prosody of a Literary Text in Pragmastylistic Interpretation]. Jazyk. Soznanie. Kommunikacija, 28, 168-182. Retrieved March 15, 2018 from http://www.philol.msu.ru/ slavphil/books/jsk_28.pdf.

Gross, H. S. \& McDowell, R. (1996). Sound and Form in Modern Poetry. Ann Arbor, MI: University of Michigan Press.

Gumovskaya, G.N. (2000). Ritm kak faktor vyrazitel'nosti hudozhestvennogo teksta: na materiale anglijskogo jazyka [Rhythm as a Factor of Expression of a Literary Text: as Exemplified by the English Language]: Unpublished PhD thesis, Moscow Pedagogical State University (MPGU), Moscow, Russian Federation.

Guseva, T. V. (2007). Prosodija rannej liriki Genriha Gejne [Prosody of the Early Lyric Poetry by Heinrich Heine]. In V.V.Vinogradov (Ed.), Lingvisticheskaja polifonija: sb. st. v chest' jubileja professora Potapovoj [Linguistic polyphony: collection of articles in honor of jubilee of Professor Potapova] (pp. 947-959). Moscow: Yazyki slavjanskih kultur.

Harding, D. W. (2010). Words into Rhythm: English Speech Rhythm in Verse and Prose (Clark Lectures). Cambridge: Cambridge University Press.

Hartman, C. (1996). Free Verse: An Essay on Prosody. Evanston, IL: Northwestern University Press.

Hench, C. \& Estes, A. (2018). A Metrical Analysis of Medieval German Poetry Using Supervised Learning. Frontiers in Digital Humanities, 5. Retrieved January 5, 2018 from https://doi.org/10.3389/fdigh.2018.00019

Holt, T. (1973). Poems by Tom Holt. London: M. and J. Hobbs/Michael Joseph.

Hughes, Ted, \& Muldoon, Paul. (1983). Texts of All the Poems Read Are Included. London: Faber \& Faber.

Kachalkina, Yu. (2004). Svobodnye ot stiha, ili Pochemu v inye jepohi gospodstvo verlibra ochevidno [Free from Verse, or Why is the Vers Libre Dominance Obvious in Certain Ages]. Znamja, 2, 204-214 Retrieved March 15, 2018 from http://magazines.russ.ru/znamia/2004/2/kachal-pr.html.

Kalashnikova, A. R. (2013). Tipy ritmicheskih modelej prozaicheskih tekstov [The Types of Rhythmic Models in Prose Texts. Jelektronnyj nauchnoobrazovatel'nyj zhurnal VGSPU Grani Poznanija, 1(21). Retrieved August 2, 2014 from http://grani. vspu.ru/files/publics/1368528124.pdf

Karpichenkova, Ye. P. (1981). Rol' temporal'nogo komponenta v ritmicheskoj organizacii stiha: (jeksperimental'no-foneticheskoe issledovanie na materiale sovremennoj anglijskoj pojezii) [The Role of the Temporal Component in the Rhythmic Structure of a Verse: (an experimental phonetic study based on the modern English poetry)]. Unpublished PhD thesis, The Maurice Thorez Institute of Foreign Languages, Moscow.

Knyazeva, E. M. (2012). Akcentno-ritmicheskie osobennosti zvuchashhego stihotvornogo teksta (na materiale russkoj pojezii XX-XXI vv.) [The Accentual and Rhythmic Aspects of the Orally Performed Poetic Text (as exemplified by the Russian poetry of the XX-XXI centuries). Unpublished PhD thesis, The Institute of Linguistics of the Russian Academy of Sciences, Moscow, Russian Federation.

Logvin, I. G. (1989). Prosodija pojeticheskogo teksta (na materiale tverdoj stroficheskoj formy anglijskogo fol'klora) [Prosody of a Poetic Text (as exemplified by the fixed stanzaic form in the English folklore): Unpublished PhD thesis, Kiev State Pedagogical Institute of Foreign Languages, Ukraine.

Mair, H. (1979). Flowers in Forest. In The Contemporary Poets Series, 5. Paisley: Wilfion Books.

Mirianashvili, M. G. (2007). Znachenie zvuchashhego i nezvuchashhego vremeni dlja ritmicheskoj organizacii sintagmy [Significance of the Vocable and Non-Vocable Tenses for the Syntagma Rhythmic Structure]. In V. V. Vinogradov (Ed.), Lingvisticheskaja polifonija: sb. st. v chest' jubileja professora Potapovoj [Linguistic polyphony: collection of articles in honor of jubilee of Professor Potapova] (pp. 473-487). Moscow: Yazyki slavjanskih kultur.

Murat, M. (2008). Le Vers Libre. Paris: Honoré Champion.

Oliynyk, N. D. (2008). Svoyeridnist' metryko-rytmichnoji struktury i styl'ovi osoblyvosti poeziji R. Bernsa (na prykladi virsha R. Bernsa LINES ABOUT WAR [The Distinctness of the Metric and Rhythmic Structure and Stylistic Features of the Poetry by R. Burns (as exemplified by R. Burns's poem LINES ABOUT WAR]. Studia Methodologica: [al'manakh], 25, 161-163 Retrieved March 15, 2018 from https://www.academia.edu/2450915/Studia_methodologica_25.

Polivanov, Ye. (1963). Obshchiy printsip vsyakoy poeticheskoy tekhniki [The general phonetic principle of any poetic technique]. Voprosy Yazykoznaniya, 1, 99-111. Retrieved March 15, 2018 from www.issuesinlinguistics.ru/pubs/oбщийфонетический-принцип-всякой-поэтической-техники.

Safronova, E. G. (1982). Intonacionnoe svoeobrazie stiha /na osnove eksper. dannyh/ [Intonational peculiarities of verse / based on exper. data]. Russkij yazyk za rubezhom, 4, 53-57. Retrieved March 15, 2018 from https://www.russianedu.ru/magazine/archive/viewdoc/1982/4/5843.html 
Scott, C. \& Evans, D. (2012). Vers libre. In S. Cushman, C. Cavanagh, J. Ramazani, \& P. Rouzer (Eds.), The Princeton Encyclopedia of Poetry and Poetics: Fourth Edition. Princeton University Press.

Shevelyova-Garkusha, N. V. (2013). Rytmiko-syntaksychna orhanizacija virshovanoho movlennya: linhvo-stylistychnyj ta linhvosynerhetychnyj aspekty (na materiali amerykans'kykh poetychnykh tekstiv XX-XXI st.) [The Rhythmic and Syntactic Structure in Poetic Speech: Linguo-Stylistic and Linguo-Synergetic Aspects (as exemplified by the American poetic texts of the XX-XXI centuries). Unpublished PhD thesis, Kherson State University, Ukraine.

Smus', M. A. (1988). Rol' foneticheskoj struktury pojeticheskogo teksta v sozdanii ritmicheskogo dvizhenija (jeksperimental'nofoneticheskoe issledovanie na materiale nursery rhymes) [The Role of the Phonetic Structure of a Poetic Text in Creating the Movement of Rhythm (an experimental phonetic research of nursery rhymes). Unpublished PhD thesis, The Maurice Thorez Institute of Foreign Languages, Moscow, Russia.

Steele, T. (1990). Missing Measures. Modern Poetry and the Revolt Against Meter. Fayetteville: University of Arkansas Press.

Suslova, E. V. (2005). Intonacija i stil' stihotvornoj rechi: na materiale pojezii XX veka [Intonation and Style of a Poetic Speech: As Exemplified by Twentieth-Century Poetry]. Unpublished PhD thesis, Samara State University, Samara, Russian Federation.

Timofeyev, L., \& Vengrov, N. (1963). Kratkiy slovar literaturovedcheskikh terminov [A Concise Dictionary of Literary Terms]. 4th ed., Moscow.

Titova, E. A. (2009). Substrat zvuchashhego i nezvuchashhego vremeni v stihotvornom tekste kak jazykovaja universalija: na materiale russkogo, anglijskogo i nemeckogo jazykov [Substratum of the Sounding and Silent Temporal Component in a Poetic Text as a Language Universal: as Exemplified by the Russian, English and German Languages. Unpublished PhD thesis, Moscow State Regional University, Moscow, Russian Federation.

Tokareva, A. I. (2009). Interpretacionnaja variativnost' prosodii v pojeticheskoj pejzazhnoj lirike [Interpretational Variability of Prosody in Landscape Lyrics]. Unpublished PhD thesis, Pyatigorsk State Linguistic University, Pyatigorsk, Russian Federation.

Vorobey, N. V. (2011). Rytmiko-syntaksychna orhanizaciya tekstiv afroamerykans'koyi poeziyi (Rhythmic and Syntactic Structure of Afro-American Poetic Texts. Visnyk Kharkivs 'koho nacional'noho universytetu im. V. N. Karazina. Serija: Filolohija, 954, 115-118. Retrieved March 15, 2018 from http://foreignlanguages.karazin.ua/resources/81a24b45feed7063aea4e9b0262f1030.pdf.

Wain, J. (Ed.). (1963). Antology of Modern Poetry. London: Hutchinson.

Zabuzhanska, I.D. (2016). Rytmichna organizaciya amerykans'kykh postmodernists'kykh poetychnykh tekstiv (eksperymental'nofonetychne doslidzhennya) [Rhythmic organization of American postmodern poetic texts (experimental and phonetic research)]. Unpublished PhD thesis, Kyiv National Linguistic University, Kyiv, Ukraine.

Zhovtis, A.L. (2013). Izbrannyye stati [Selected Articles]. Compiled by S.D. Abisheva, Z.N. Pole. Almaty.

Zlatoustova, L. V. (1962a). Foneticheskaya struktura slova v potoke rechi [Phonetic structure of the word in speech]. Kazan: Izd-vo Kazanskogo un-ta.

Zlatoustova, L. V. (1962b). Foneticheskoe slovo v stihe i penii [The Phonetic Word in Verses and Songs]. Kazan: Izd-vo Kazanskogo un-ta. 